\title{
ALLEVIATING CULTURE SHOCK EXPERIENCE AMONG NIGERIAN STUDENTS STUDYING ABROAD: EFFECTS ON MIGRATED NIGERIAN STUDENTS STUDYING ABROAD
}

\author{
Lillian I. Olagoke-Oladokun*, Mahani Mokhtar and Zainudin Bin Hassan \\ School of Education, Universiti Teknologi Malaysia, Malaysia \\ *Corresponding Author Email: lilliangoke@gmail.com
}

This is an open access article distributed under the Creative Commons Attribution License, which permits unrestricted use, distribution, and reproduction in any medium, provided the original work is properly cited

\section{ARTICLE DETAILS}

\section{Article History:}

Received 01 April 2019

Accepted 30 May 2019

Available online 10 June 2019

\section{ABSTRACT}

\begin{abstract}
This study is an exploratory research aimed at investigating social cultural factors that are problematic to Nigerian students studying abroad using Malaysia as a study area. This is with a view of alleviating the culture shock experience among them. Extensive qualitative research approach was employed through personal interview with 20 participants with the aid of semi-structured questionnaires. Content and thematic analysis was adopted for data analysis. The study revealed the determinant factors of culture shock experience among Nigerian students. The originality of the study was to enable students migrating from Nigeria to be aware of what they will likely to experience in getting to abroad for study and get them prepared. This will assist in reducing the effect of culture shocks among them. The study suggested some workable ways to assist Nigerian students, the institution and the Malaysian ministry of higher education through which the post graduate program can be more effective and attract more international students.
\end{abstract}

\section{KEYWORDS}

Culture, Culture Shock, Food, Language, Malaysia, Nigerian Students

\section{INTRODUCTION}

Students leaving their countries for another in search for knowledge have been in existence for years and this has been a major concern for educational researchers [1]. Advocate for secularism such as the spread of democratic values, transmission of educational practices and the promotion of international harmony justifies one of the reasons why scholars opt for international education in search of knowledge.

Although countless benefits of international education have been enumerated but, its social-cultural effects on the recipients could be negative. This phenomenon of having a negative feeling or anxiety while in foreign country and resulting to losing familiar cues is known as culture shock [2]. Moving to a new cultural environment brings about one of the most traumatic events a person could ever experience as this moment is accompanied with different difficulties and confusions on what and how to do things which are generally carried out with ease while in the country of birth [3]. Students are challenged to adapt their behavior and values in response to socio-cultural situations in host culture, and they in returns are stimulated to expand their capabilities for cross-cultural communication and intercultural understanding $[4,5]$.

Students from African continent with reference to Nigeria are part of these migrants who made Malaysia a stopover point for their educational pursuit. Nigerian students like other international students are likely to experience culture shock because of the loss of familiar social and cultural ideas which they have been attached to from childhood [6]. Therefore, this study aimed at investigating Nigerian students' experience in terms of culture shock in Malaysia with a view of suggesting measures to alleviate culture shock experience among them.

\section{LITERATURE REVIEW}

\subsection{International Students}

a previous researcher defined International students as students that are enrolled in an institution of higher education in a country where they are neither citizens nor refugees nor immigrants [7]. The importance of going to foreign country to study have been identified to include the following: acquiring of knowledge, enhance personal growth, increase language proficiency, develop a new habit of thinking and increase cultural contact [8]. Students pursue international study to explore different culture, learn new ways of thinking and behaving, make new friends and improve their cross-cultural knowledge and skills [9]. A group of researchers discovered that international education is becoming important to Malaysia and a source of revenue apart from oil, gas and tourism [10]. However, institution that failed to address the important needs of international students will lead the students to feel disappointed, unfulfilled and exploited [11].

\subsection{Culture shock}

Culture shock was defined as the process of early adjustment to an environment one is not familiar with [12]. This situation occurs when one moves to a foreign country which could either be for a temporary period or otherwise. This situation occurs when one moves to a foreign country 
which could either be for a temporary period or otherwise. At this particular time, everything is unfamiliar, both the social environment (etiquette and habitual ways of doing things) as well as the physical settings such as road maps, stores, school environment [13]. Basically, it is the anxiety which comes with loss of familiar signs and symbols of social interaction and substituting them with strange ones [14]. Culture shock is a phenomenon in which an individual experience problem in adapting to cultures that are different from their own and this is manifested as anxiety, sadness, rejection of host culture and social isolation $[15,16]$. At this point, such an individual usually feel odd, loose self-esteem, become confused and miserable feel disoriented and, uncomfortable. It is also the disorientation, discomforts and difficulties people face when confronted with, language, food and accommodation and other social issues in a foreign nation.

\subsection{Language}

This refers to ways which information are been disseminated to international students both in class and outside the class. Language helps in communication of thoughts, but difficult when there are language differences. Often times, international students are very lonely in their new environment, such loneliness includes not only the lack of familiar friends and social networks, but also the lack of familiar cultural and/or linguistic environments $[17,18]$. According to a study, lack of proficiency in a host country's language has been known to contribute to increased anxiety for international students [19]. Studies has shown there is always a difficulty for non-native speakers of a given language in every environment of which international students are most likely not left out of this category. Therefore, overcoming the language barrier is important to their academic accomplishment and wellbeing.

\subsection{Food}

Food is any substance consumed to provide nutritional support for the body. Food is a symbol of culture and varies from one culture to another [20]. This study considered food in respect to restriction in nutritional intake due to absence of Nigerian students' native food and also changing meal pattern in foreign country. It was affirmed that some degree of food shock is inevitable for student migrants who find themselves in another country and this make them to be devastated on arrival to a new environment. One characteristic that often works against individuals consuming a varied diet is 'Food Neophobia'; a condition known to be a refusal of foods that are new or unknown [21].

A previous researcher in their study discovered food neophobia are problematic and resulted in negative effects on students' diet and health [22]. A scholar opined that eating food from the student's home country helps in alleviating homesickness of the students [23]. However, he opined that eating food from the student's home country helps in alleviating homesickness of the students.

Cahill and Stavrianeas (2013) used data from college freshmen in United States universities as a comparative group to understand the potential psychological and physiological stressors of international students living abroad. The findings revealed that actual and perceived barriers hinder the international students' ability to develop healthy living and eating patterns. Hence, it was recommended that universities which host international students should offer nutritional and physical education programs that support and boost a healthy and active lifestyle. Brown (2009a) explained that emotional ties to home food is a result of the positive link between familiar taste and nostalgic thoughts of home and acceptance. It was found that perception of English and Pakistani foods among British born Pakistani people indicated home food to be associated with family bond, maternal love and cultural belonging. Brown (2009a) affirmed the strong connection between cultural identity and food choices. Concerning the physical health of immigrants, studies showed that depreciated health (including a higher incidence of obesity and diabetes) was associated with an increased consumption of Western food which the international students were not used to.

\subsection{Accommodation}

This study considered accommodation in terms of its affordability on campus and off campus. A researcher discovered that international students face difficulties before they get accommodation [24]. A researcher in their study highlighted the importance of pre-arrival information not just with course material but also with accommodation and directions [25]. A researcher used a video to provide information to potential students in order to highlight some of the problems that students might face. Apart from educational issues, accommodation and safety are other issues that play important role in the satisfaction of the international students. Students expects accommodation to be provided by the universities or private agencies to conform to least standards of luxury, at a reasonable cost and made available when it is needed. Negative experiences relating to accommodation includes the cost and lack of accessible information which make them to regard it as one of the worst experiences they encountered in their host countries.

\subsection{Causes and effects of Culture shock}

Culture shock is an inevitable experience is a usually associated with an individual migrating to a new environment. It is due to cultural differences and distance that exist between the host and the migrant's country or familiar environment. A researcher opined that culture shock is caused by various factors such as coming to a new environment or encountering a new situation [26]. This environmental or situational explanation advocates that all persons will experience certain levels of culture shock in foreign environment. Secondly, culture shock occurs due to ineffectiveness of intercultural or relational communication. Explaining culture shock resulting from communication difficulties leads people to have misunderstanding, misperception and wrongly envisage of one another behavior. Thirdly, culture shock is triggered by a threat to the emotional or intrapsychic well-being of the migrant. Fourth, culture shock establishes the need to adjust behavior adequately and to regain positive reinforcement from the new culture. This behavioral viewpoint describes culture shock as a reaction to needs and wants to lead to inappropriate behaviors. Fifth, culture shock is caused by a "growth experience because during this process, an individual learns new values from the host culture. A previous researcher asserted that culture shock is a normal experience that does not necessarily indicate deficit or abnormality [27]. Therefore, to cope with the difficulties of getting used to a new environment, a researcher posited that, the migrant need behavioral modification that entails developing a new pattern of living to match with the demands of the new society [28]. However, this behavioral modification process always proved difficult. This is because, the old habits which has been learnt from one's culture are not easily put off.

\subsection{Social support Measures}

Social support is defined as verbal and non-verbal communication between recipient and providers to reduce uncertainty about the situation, self, relationship and function to enhance a perception of personal control in one's life experience $[29,30]$. From this definition, social support is any type of communication which helps an individual feel more certain about a given situation and thereby having control over such situation. Therefore, social support measures are the courses or plans of actions taken to bring about social support [31]. They are usually medium to ameliorate the adjustment problems encountered by the migrants. On arrival, students need to be introduced to peers and academic staff as soon as possible. A good induction programme to teaching, learning styles and inclusion in social activities are part of positive learning experience $[32,33]$. According to a research, the social support theory places greater importance on the quality and quantity of support than the actual support network for the students [34]. According to him, the host country can provide assistance and contribute to the improvement of psychological well-being of such students. However, a researcher opined lack of social support network satisfaction was a significant predictor of acculturative distress. Whereas, students with higher levels of social support experienced lower levels of acculturative stress, while international students may have friendships and academic supports within their cultural groups, majority of them do not make viable links with local students [35]. This can however hinder their access to support inside and outside the university thereby obstruct the achievement of important culturally specific information with a negative effect on adjustment outcomes [36].

Therefore, a researcher suggested social support programs to be carried out in colleges and universities to improve student migrants' academic, cultural and social adjustments difficulties [37]. 


\section{OBJECTIVE}

The main objective of this study is to investigate the social cultural factors that are problematic to Nigerian students studying abroad using Malaysia as an area of study. This is with a view of alleviating culture shock experience among intending Nigerian students who will migrate to Malaysia to further their education.

\section{METHODOLOGY}

Inductive qualitative approach was employed in this study patterns, themes and categories of analysis to come from the data and not decided or known before the data were collected [38]. Using a qualitative approach, phenomenology design was adopted because the researchers seek to explore and get detailed information or knowledge and experiences about the phenomenon of culture shock among migrated Nigerian students In Malaysia. According to a study this is to rely on their opinion or the perceptions of their experiences and beliefs [39]. Twenty postgraduate students in either $\mathrm{PhD}$ or master's degree program as participants were purposively selected because they are Nigerians who migrated to Malaysia to continue their education and interviewed using semi- structured open-ended question. The data collected were transcribed followed by coding while the analysis description and themes generation were by through content and thematic analysis. Data coding involved segmenting and labelling text to form descriptions and broad themes in the data. For validity and reliability, member checking technique was adopted.

\section{RESULTS}

Findings from this study revealed the issues of language barrier which translated to perceived unfriendly attitude of the locals, food, accommodation and lack of social support were the major causes of culture shock to migrated Nigerian students in Malaysian universities.

\subsection{Language barrier}

Most respondents opined that the poor association between the Malaysians and the Nigerian students might not be a deliberate but might be because of communication barrier. As one of the respondents explained: "very difficult to associate with Malaysian, because of the communication gap, associate majorly, with my Nigerian friends but few locals from my church." (Kayin, IQB2).

Another Nigerian student also showed

"bridge between the Nigerian and local student., communication gap, we don't tend to flow, very difficult, things you want to find out, in the faculty or school, locals have access to such information, very hard to get those things or it takes a longer process" (Callie, IQB1).

"Our culture at home welcome people and when seeing person second you time, you smile" whereas the culture here presents them so reserved, the way they interact, smiles are not natural, is like they force a smile on them, (Faithia, IQ3B)

They are freer to their people but not to the non-indigenes" (Stean, IQ3B).

\subsection{Food}

Another area where Nigerian students experience culture shock was in the issue of food. Study showed the students complained of the lack of access to their local food both on campus and in town.

"Hmnn...precisely, what frustrates me most is the food stuff new environment.... you have to struggle hard to adapt to the type of food they eat." (Ishaku, RQ1B).

Another student also identified lack of variety in the Malaysian food.

"Malaysia food is built around one called "nasi" or "rice" it's really difficult for me as Nigerian student to enjoy it" (Callie, IQ3B).

"Malaysian food is quite different from ours... their foods are light, Africans foods are solid foods, heavy food when we were here newly could not eat for one week they use sugar in their food, Africans we use salt we were shocked seeing people eating food with, eating food cooked with sugar" (Mathew, IQE2).

So, in order to be able to overcome these challenges on food most of them resorted to cooking most of the time and this had a toil on their academics. As they have to devout time to cooking.

"I cook, most of their food has sugar, we are not used to it, I have to cook" (Ishaku, IQE1).

\subsection{Accommodation}

Study showed a lot of thing that cause culture shock experience among Nigerian students which invariably make them to be dissatisfied on the accommodation within the nation. Among these are High cost, lack of good facilities and cooking.

Facilities are very ok issue is the synchronization between those facilities and price tag attached to it" (Callie, IQD1).

"the accommodation is expensive for we the internationals, but comfortability, its fair." (Ishaku, IQD1).

"It is comfortable....... except to cook, more expensive" (Kayin, IQD1).

Although the accommodation outside the campus is cheaper but findings revealed challenges of security and mobility. A respondent stated the reasons why he cannot afford to stay off campus: “....., why I shouldn't move out is my security, ......mostly you cannot relate with most of them, you are a total stranger, anything that happens to you, you are on your own, despite it is cheaper , accommodation on campus is totally more expensive. We take it just because of security which you cannot pay for outside." (Stean, IQD2).

\subsection{Social support Measures}

Findings revealed that there was no social support provision made by the institution on the arrival of the Nigerian students. Their experience on their arrival day include no airport pick up, no direction and taxi drivers' extortion: "I will say actually first 1-2 weeks it wasn't easy... ......, the communication... if you have to ask you are going to a place if you don't see somebody maybe who a foreigner is or maybe somebody who understands you a little, you are... doomed!!!". (Stean, IQG, 1)

I ...... was disappointed at the treatment I received from the taxi drivers ...., we had to start negotiating within the twinkle of an eye..., they increased the fares .... we had no choice than to board the last fare they gave us so that was the" (Abdul, IQG, 1).

"It wasn't a pleasant one. There was no arrangement by the school to pick us up. I found my way to the school but couldn't locate ISC, (Kayin, IQG, 1).

\section{DISCUSSION}

Findings from this study revealed language barrier which lead to a perceived discrimination, a perceived unfriendly attitude of the locals and language difference was experienced on the signage leading to more difficulty confusion in locating places. These findings are in agreements with previous researches on language difficulty amongst international students carried out by a previous researcher [40,41].

Nigerian students experienced shock regarding limited food varieties, the method of cooking, food difference in food types, methods of cooking, tastes of the food. Students stated in Malaysia they were limited to one variety of food. Students attested the taste of food got better with time. This can be said to mean that the process of acculturation is dependent on the time spent in the host country. Findings showed another major shock these students experienced was due to the cost of accommodation, this was increased due to the fact that there was no source of income for the students in the host country. Due to the opportunity for students to work, they experienced difficulties in the cost of living.

\section{CONCLUSION AND RECOMMENDATION}

Without doubt, Nigerian students experienced culture shock in Malaysia due to the cultural differences which exist between the two societies. 
However, the students in turn attested while in Malaysia, they adopted some values patience in relating with others being reserved, as it results in peaceful co-existence. It can therefore be inferred that culture shock is inevitable experience for migrants however, there are lot of values that can be learnt from every society. In view of this, culture shock is not a negative phenomenon and cannot be totally neglected in the society. It is a period every individual is been transformed to conform to the norms of the new environment to enhance personal development.

To alleviate the negative effects of culture shock among Nigeria student when migrating to Malaysia to study, the authors are of opinion for proper orientation and training on the Malaysia culture to admitted students prior to their journey. This can be achieved by putting necessary information which can be of help to the international student on the institutional website. These can be in form of video coverage explaining the culture and way of life of the citizens. For intending students especially Nigerian students, they must be ready to adopt familiarize themselves with the host culture through reading and asking people that have been in such country questions. Importance of adequate preparation on the side of students to adopt the host culture cannot be over emphasized as this will help them to quickly and easily adapt with this, culture shock among Nigerian students migrating overseas for study will totally alleviated. This study is limited to Nigerian students' social integration and adaptive measure in coping with culture shock. In addition, the authors also suggest for the Malaysian government in the area of incorporating Englishlanguage into the curriculum of their education system to enhance the productivity of the staff and make them more effective in their communication. If this is well taken care of by the Malaysian Ministry of higher education, the educational market of Malaysia will have a turn around. This is because if the language barrier is overcome, it goes a long way to determine the success and well-being of the international students. Therefore, if Malaysian government will support the educational system by fully implementing the use of the English language in the curriculum, then the country will experience influx of international students in her market. Lastly, effects of culture shock on the students' academic performance is not within the scope of this present study, therefore, the authors are of opinion that further research can be made in this area.

\section{REFERENCES}

[1] Ward, C., Bochner, S., Furnham, A. 2001. The Psychology of Culture Shock. Philadelphia, Taylor and Francis.

[2] Anderson, N. 1981. Culture Shock: Helping Our Students Adjust. Deseret Language and Linguistic Society.

[3] Brown, L. 2009a. The Role of Food in the Adjustment Journey of International Students. The new cultures of food: Marketing opportunities from ethnic, religious and cultural diversity, 37-56.

[4] Yang, M., Webster, B., Prosser, M. 2011. Travelling a Thousand Miles: Hong Kong Chinese Students' Study Abroad Experience. International Journal of Intercultural Relations, 35(1), 69-78.

[5] Talebloo, B., Baki, R.B. 2013. Challenges Faced by International Postgraduate Students During Their First Year of Studies. International Journal of Humanities and Social Science, 3(13), 138-145.

[6] Michie, M.G. 2011. Identity Learning, Culture Shock and Border Crossing into Effective Teaching in Indigenous Science Education.

[7] Arambewela, R., Hall, J. 2008. A Model of Student Satisfaction: International Postgraduate Students from Asia. European Advances in Consumer Research, 8, 129-135.

[8] Pyvis, D., Chapman, A. 2007. Why University Students Choose an International Education: A Case Study in Malaysia. International Journal of Educational Development, 27(2), 235-246.

[9] Brown, L. 2009b. The Transformative Power of the International Sojourn. Annals of Tourism Research, 36(3), 502-521.

[10] Yusoff, Y.M., Chelliah, S. 2010. Adjustment in International Students in Malaysian Public University. International Journal of Innovation, Management and Technology, 1(3), 275-278.
[11] Pelling, A.C. 2000. Culture Shock of International Students in Canada. Master of Education, Lethbridge, Alta.: University of Lethbridge, Faculty of Education.

[12] Rempel, J.N. 2011. Coping Strategies for Culture Shock as Indicators of Cultural Identity. Journal of Undergraduate Anthropology, 49.

[13] Zhou, Y., Jindal-Snape, D., Topping, K., Todman, J. 2008. Theoretical Models of Culture Shock and Adaptation in International Students in Higher Education. Studies in Higher Education, 33(1), 63-75.

[14] Brown, L., Edwards, J., Hartwell, H. 2010. A Taste of the Unfamiliar. Understanding the Meanings Attached to Food by International Postgraduate Students in England. Appetite, 54(1), 202-207.

[15] Pedersen, E., Neighbors, C., Larimer, M., Lee, C. 2011. Measuring Sojourner Adjustment among American Students Studying Abroad. International journal of intercultural relations: IJIR, 35(6), 881-889.

[16] Irwin, R. 2009. Culture Shock: Negotiating Feelings in the Field. Anthropology Matters, 9(1).

[17] Sawir, E., Marginson, S., Deumert, A., Nyland, C., Ramia, G. 2008. Loneliness and International Students: An Australian Study. Journal of Studies in International Education, 12(2), 148-180.

[18] Sherry, M., Thomas, P., Chui, W.H. 2010. International Students: A Vulnerable Student Population. Higher Education, 60(1), 33-46.

[19] Cahill, C.R., Stavrianeas, S. 2013. Assessing Dietary Changes in International Students and the Barriers to Healthy Living Abroad: A Review. Journal of Exercise Physiology Online, 16(4).

[20] Henslin, J.M. 2005. Sociology: A Down to Earth Approach. (7 ed). Boston, Pearson Education (US).

[21] Flight, I., Leppard, P., Cox, D.N. 2003. Food Neophobia and Associations with Cultural Diversity and Socio-Economic Status Amongst Rural and Urban Australian Adolescents. Appetite, 41(1), 51-59.

[22] Dovey, T.M., Staples, P.A., Gibson, E.L., Halford, J.C. 2008. Food Neophobia and 'Picky/Fussy'eating in Children: A Review. Appetite, 50(2), 181-193.

[23] Edwards, J., Hartwell, H., Brown, L. 2010. Changes in Food Neophobia and Dietary Habits of International Students. Journal of human nutrition and dietetics, 23(3), 301-311.

[24] Burnard, P. 2005. Issues in Helping Students from Other Cultures. Nurse education today, 25(3), 176-180.

[25] Amaechi, A., Bennett, C., Kafilatu, G., Kayit, I., Lillyman, S., Okeke, J. and Paticiente, T. 2013. Laying Down the Foundations for International Student Journey. Students as Academic Partners Project Report. Worcester Journal of Learning and Teaching, 8, 24-35.

[26] Dongfeng, L. 2012. Culture Shock and Its Implications for CrossCultural Training and Culture Teaching. Cross-Cultural Communication, $8(4)$.

[27] Brown, L., Holloway, I. 2008. The Initial Stage of the International Sojourn: Excitement or Culture Shock? British Journal of Guidance \& Counselling, 36(1), 33-49.

[28] Marx, E. 2001. Breaking through Culture Shock: What You Need to Succeed in International Business. Nicholas Brealey Publishing.

[29] Lee, J.Y., Ciftci, A. 2014. Asian International Students' Socio-Cultural Adaptation: Influence of Multicultural Personality, Assertiveness, Academic Self-Efficacy, and Social Support. International Journal of Intercultural Relations, 38, 97-105.

[30] Yeh, C., Inose, M. 2002. Difficulties and Coping Strategies of Chinese, Japanese and Korean Immigrant Students. Adolescence. 
[31] Cleary, P.D. 2017. Social Support: Conceptualization and Measurement. Evaluating Family Programs. 195-216. Routledge.

[32] Hartwell, H.J., Edwards, J.S., Brown, L. 2011. Acculturation and Food Habits: Lessons to Be Learned. British food journal, 113(11), 1393-1405.

[33] Hughes, R., Serebryanikova, I., Donaldson, K., Leveritt, M. 2011. Student Food Insecurity: The Skeleton in the University Closet. Nutrition \& Dietetics, 68(1), 27-32.

[34] Olivas, M., Li, C.S. 2006. Understanding Stressors of International Students in Higher Education: What College Counselors and Personnel Need to Know. Journal of Instructional Psychology, 33(3).

[35] Poyrazli, S., Grahame, K.M. 2007. Barriers to Adjustment: Needs of International Students within a Semi-Urban Campus Community. Journal of Instructional Psychology, 34(1).

[36] Furnham, A. 2004. Education and Culture Shock. Psychologist, 17(1), 16.
[37] De Araujo, A.A. 2011. Adjustment Issues of International Students Enrolled in American Colleges and Universities: A Review of the Literature. Higher Education Studies, 1(1).

[38] Dana, L.P., and Dana, T.E. 2005. Expanding the Scope of Methodologies Used in Entrepreneurship Research. International Journal of Entrepreneurship and Small Business, 2(1), 79-88.

[39] Creswell, J.W. 2012. Educational Research: Planning, Conducting and Evaluating, Quantitative and Qualitative Research. (4th ed). Boston, Pearson.

[40] Sawir, E. 2005. Language Difficulties of International Students in Australia: The Effects of Prior Learning Experience. International Education Journal, 6(5), 567-580.

[41] Zhang, Y., Mi, Y. 2010. Another Look at the Language Difficulties of International Students. Journal of Studies in international Education, 14(4), 371-388.

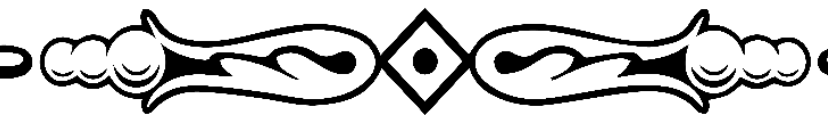

